\title{
Platform-mediated short-term rentals and gentrification in Madrid
}

Urban Studies

$|-2|$

(C) Urban Studies Journal Limited 2020 Article reuse guidelines: sagepub.com/journals-permissions DOI: $10.1177 / 0042098020918154$ journals.sagepub.com/home/usj @SAGE

\section{Alvaro Ardura Urquiaga}

Universidad Politecnica de Madrid, Spain

\section{Iñigo Lorente-Riverola}

Universidad Politecnica de Madrid, Spain

\section{Javier Ruiz Sanchez}

Universidad Politecnica de Madrid, Spain

\begin{abstract}
Gentrification demands updated frameworks to assess the impact of some major global trends on the local populations' access to housing. Short-term accommodation using digital platforms in previously gentrified central urban areas is playing a significant role in outlining a new wave of 'transnational gentrification' in a number of global cities. Having undergone classical patterns of gentrification over the last two decades, the central district of Madrid and its surroundings are showing patterns of a new wave of gentrification in a context of economic crisis, planetary rent gaps, increasing global tourism and an increase in rental prices in central areas that may be related to the emergence of short-term rentals - making Madrid a relevant case for depicting transnational gentrification in the Southern European capitals. Based on empirical data, this work explores the holiday rental supply in Madrid over three years (2015-2018), verifying a strong association between the growth in tourist arrivals, the settlement of new residents from wealthy economic backgrounds and increasing rental prices. Since this process is accompanied by deregulation of local rental contracts and the growth of transnational Real Estate Investment Trusts (REITs), even in some of the most vulnerable areas located beyond the M-30 ring road, this wave of gentrification has the potential to produce displacement and substitution of residents.
\end{abstract}

\section{Keywords}

gentrification, holiday rentals, Madrid, touristification, urban segregation 


\section{摘要 \\ 绅士化要求更新框架, 以评估一些重要的全球趋势对当地居民获得住房的影响。在此前 已完成绅士化的中心城市地区, 使用数字平台出租的短租房在描绘一些全球城市的新一 波“跨国绅士化”方面发挥着重要作用。在过去20年里经历了传统的绅士化模式后, 马德 里市中心及其周边地区正呈现出新一轮绅士化的模式, 其背景是经济危机、全球租金差 距、全球旅游业增长以及中心地区租金价格上涨（这些都可能与短租房的出现有关）, 这使得马德里成为了描绘南欧国家首都跨国绅士化的一个相关案例。基于实证数据, 本 研究探讨了马德里在三年内（2015-2018年）的假日租赁供应, 验证了游客数量的增长、 来自富裕经济背景的新居民的定居和租金价格的上涨之间的高相关性。由于这一过程伴 随着对当地租赁合同的放松管制和跨国房地产投资信托 (REIT) 的发展, 即使在位于M-30 环路以外的一些最脆弱的地区, 这一绅士化浪潮也有可能造成居民被排挤和取代。}

\section{关键词}

绅士化、假日出租、马德里、旅游化、城市隔离

Received September 2018; accepted March 2020

\section{Introduction}

'Classical gentrification' (Lees et al., 2008: 10) can be understood as a substitution of the resident population in some areas of cities by higher-income classes following periods of social and economic decline. Its most relevant characteristic is the rise in the cost of living according to the newcomers' standards, which eventually may force lowerincome residents to find new areas in which to live. In recent years, the middle class's growing access to tourism, the globalisation of real estate operations that take advantage of planetary rent gaps and the emergence of new platforms providing access to shortterm accommodation in private residences are broadening the spectrum of locations and circumstances under which gentrification can take place. Madrid is an example and an appropriate case study for this phenomenon.

For the last 40 years, the Centro district of Madrid has undergone significant transformations that have evinced classical gentrification. After a period of decline (Leal, 2004), the reputation, activity, demography and household size of some of its six administrative quarters have changed significantly - especially after the 2008 financial crisis (Table 1). In particular, the transnational residential relocations from higherincome countries - both in the longer and shorter term - to the city have drastically changed the gentrification landscape of Madrid. Its urban amenities and cultural collections (acquired over a long history of transcontinental empire), coupled with its lower housing costs (relative to Northern Europe) and easy accessibility for short-stay tourists, have contributed to an influx of new, mobile workers and visitors, who have partially displaced lower-income populations from the city's centre, including those of lower-status mobile workers from the Global South. Madrid is an illustrative case of these new processes of transnational gentrification because of its semi-peripheral status, where, like Lisbon (Sequera and Nofre, 2019) and Barcelona (Arias Sans and Quaglieri, 2016; Cocola-Gant and López-Gay, 2020, this issue), housing stock has been transformed from longer-term stock to short-term tourist uses. From a visitor's perspective, short-term residential accommodation can provide a 


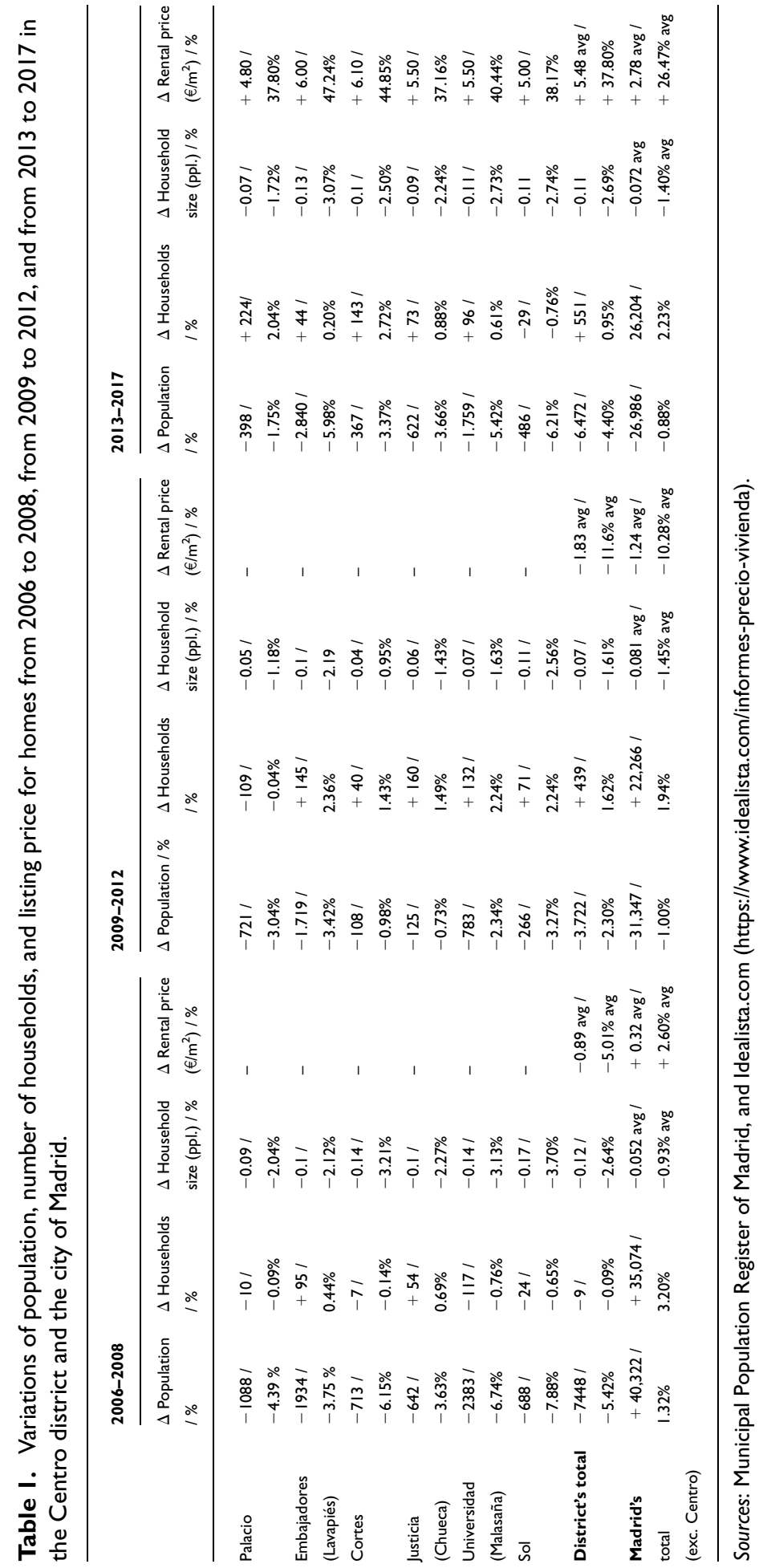


more 'authentic' local experience than a hotel, at an overall more affordable price (Füller and Michel, 2014; Novy, 2019). For landlords, either renting complete apartments or monetising unused housing capacity can be a more profitable alternative to the conventional real estate market (López García, 2018; Pérez et al., 2015; Red2Red Consultores, 2017). This situation changes the classical landscape of gentrification, as contributors to this Special Issue argue.

The aim of this paper is to provide empirical evidence of a new 'transnational gentrification' (the arrival of wealthy migrants who change the socio-economic character of certain areas of Madrid), neighbourhood upgrading that correlates with the rapid increase since 2013 in platformmediated, short-term rental supply and rising rental costs. Madrid offers an empirical site for thinking about key concepts and theories of gentrification in light of contemporary, global forces of real estate accumulation and population mobility. It challenges the prism of non-overlapping waves of gentrification that scholars have used to describe the phenomenon in the Anglo-American context (Aalbers, 2019; Hackworth and Smith, 2001; Lees et al., 2008), broadening the empirical framework of transnational gentrification linked to new forms of hybrid real estate and short-term accommodation. Moreover, it shows how the transformation of housing stock from long-term single use to shorter-term, multiple use, challenges the meaning of cities, potentially disrupting communities based on place-based ties and shared daily understandings of place. The paper is organised into five sections. The first section provides context for contemporary transformations, fitting Madrid's contemporary gentrification within a longer historical timeline. The second reviews the recent theoretical contributions on the mutation of gentrification processes, such as the concepts of transnational gentrification, planetary rent gaps and recent updates to the wave model theory. The subsequent two sections provide details of the methodology and the results of our study of Madrid. Finally, we conclude that transnational gentrification is a characteristic of fifth wave gentrification processes in Southern Europe.

\section{From classical to transnational gentrification in Madrid}

Madrid's first gentrification processes can be traced back to the late 1970s and 1980s (Figure 1). Chueca (in the Justicia administrative quarter) evolved from being one of the main drug-dealing areas in the city to becoming the LGBT + neighbourhood of Madrid, constituting the city's first great urban success story. Malasaña having been the centre of 'la Movida' (Götte, 2014; Lechado and García, 2005), ${ }^{1}$ state-led regeneration initiatives turned it (Universidad quarter) into a so-called 'hipster' area (Davidson, 2008). In order to renew obsolete urban infrastructure, improve public space, promote local commerce and revitalise a declining neighbourhood in the central district, which had lost $14.6 \%$ of its population between 1986 and 1996 (Justo, 2011), the municipal government established a special Area de Rehabilitación Preferente (ARP, or in English, 'preferential rehabilitation area') around Dos de Mayo square in Malasaña in 1994. A year later, it extended it to the South (López de Lucio et al., 2016). The plan also incentivised building restoration to attract developer interest in properties. In the same fashion, the municipality launched a programme in 2006 to renovate the southern part of the neighbourhood ('ARI Pez-Luna', in English 'integrated rehabilitation area'). In 2008, a private operator attempted to rebrand the south-eastern part of Malasaña, largely known as the red-light district, with the acronym TriBall (Triángulo Ballesta, 


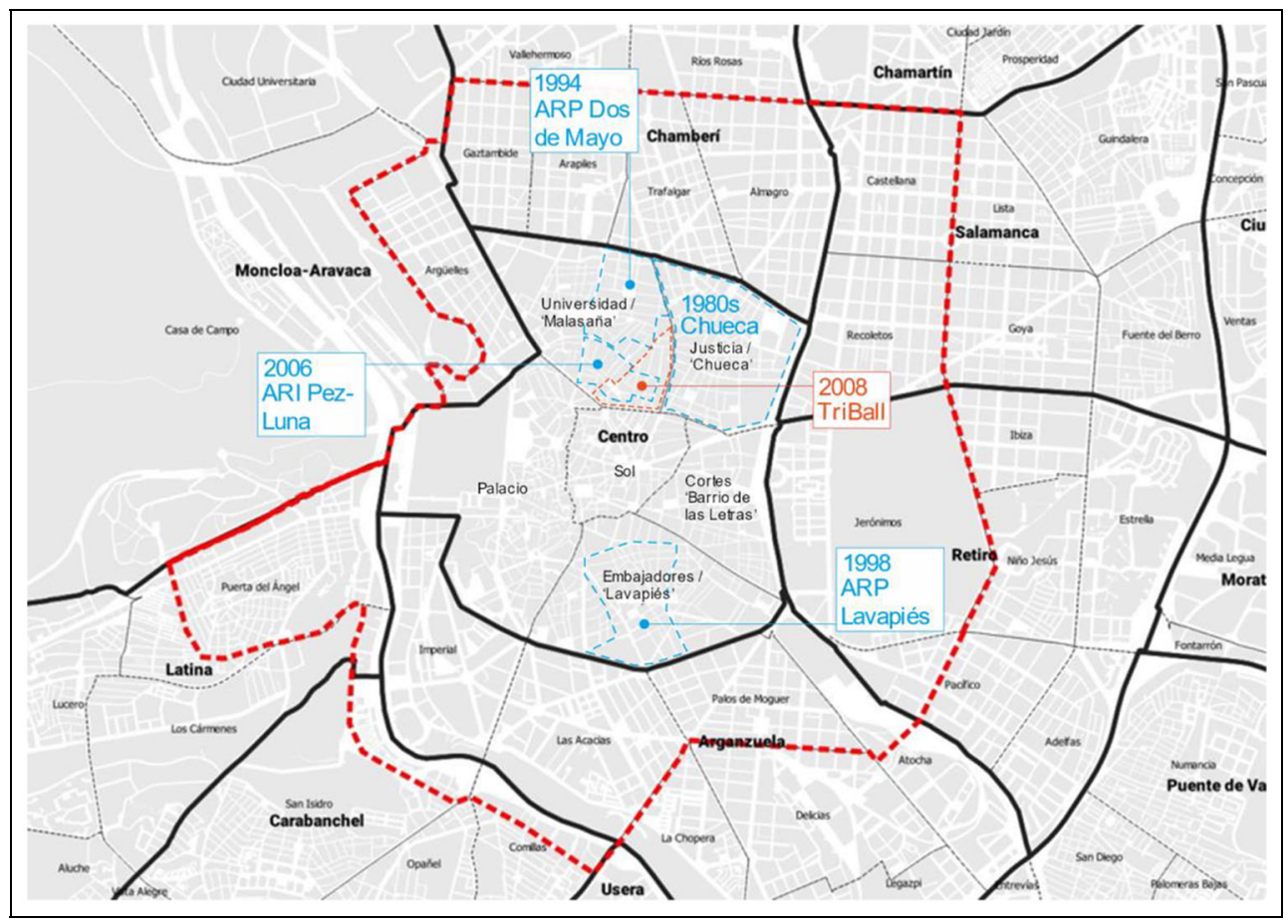

Figure I. Map of the Centro district and its surrounding administrative quarters. The thick dashed line represents its best-connected surrounding neighbourhoods.

following the examples of names such as SoHo or NoLIta in New York) to create a leisure area focused on art, culture and design. This was the paradigmatic case of private, commercially induced neighbourhood gentrification in Madrid (Janoschka et al., 2014; Sequera and Janoschka, 2015). In 1998, the municipality launched a regeneration programme for Lavapiés (in the Embajadores quarter). The neighbourhood is well known as Madrid's 'melting pot', as it has traditionally received a significant share of foreign-born residents. ${ }^{2}$ Just as in Malasaña, the ARP was managed by the local authority with contributions from national and regional administrations, providing public funds for refurbishment of private buildings with no oversight of their effect on real estate prices. Similarly, the social composition of the neighbourhood was changing, as it drew more members of the so-called 'creative classes' (Florida, 2002) or, more critically, members of an intellectual bourgeoisie (Garnier, 2017; Ley, 1996) as well as some left-wing municipal social movements.

The spatial peculiarities of each area give the illusion of a graduated gentrification, with different degrees of urban transformation that vary from a mature stage in the more 'noble' Chueca to a partially concluded, ongoing process in Lavapiés, where building quality is lower and residential units smaller (García Peréz, 2014: 76). These characteristics have helped Lavapiés retain its active social movement networks (Sequera, 2013), especially the anti-eviction movement. At present (2018), Malasaña is considered to 
be in an intermediate stage, with renovations for the private market rather than for the public interest leading the transformation of the neighbourhood. In these areas, where a higher degree of housing stigmatisation was used as a political alibi for privatised urban regeneration in the 1990s, first stage gentrification in Chueca and Malasaña coincided with the speculative expansion of the Spanish economy, which accelerated displacement of lower-income groups. Later urban regeneration projects (Lavapiés and the southern part of Malasaña) coincided with the end of the expansionist economic cycle, mitigating some displacement (Sorando and Ardura, 2018).

The 2008 global real estate crisis led to a $40 \%$ drop in housing prices on a national level, both in sale and rental markets, from a peak in 2007 Q3 to a trough in 2014 Q1. $^{3}$ Despite that, Centro's population remained stable until 2011 and, due to pre-crisis gentrification, some of its residents may already have been economically less vulnerable. During the crisis, however, housing prices in the district fell for five consecutive years, until they began to bounce in 2013 (up 26\% over 2011), and population in Centro began to fall (6\% over 2011 data). Although some other districts experienced larger decreases in the cost of real estate after the crisis, Centro offered better conditions for realising potential rent increases, as is characteristic in gentrified areas (Hammel, 1999). Despite the loss of population, most neighbourhoods grew slightly in the number of households during the 2011-2017 period. The combination of factors - skyrocketing housing prices, loss of population but stabilisation in the number of households as additional units are brought onto the market - allows us to make the initial assumption that Centro may have become attractive for a new group of residents with higher incomes or fewer economic restraints. It also leads us to question the population data used by the Municipal
Population Register. The main reason for the residents to put themselves on the Register is the possibility of accessing certain services - traffic and parking permissions and, above all, public health assistance, of particular importance in Spain. As the duration of stay of short-term visitors is not comparable with renters and owners, there is no need for them to have access to these public services. Short-term foreign residents - often neither traditional tourists nor neighbours in the conventional sense - may not be in the Register. This has led to suggestions that the population data may over-estimate population loss (Sorando and Ardura, 2018).

Of course, digital platforms greatly facilitate increased spatial mobility and, as these emerged after 2012 - especially Airbnb Madrid's value as a tourist hub drastically shifted the real estate market. This created a rent gap - but not for the local real estate market, since there was little additional higher-income demand from Spanish workers. Instead, on a European and even global scale, the relatively low cost of Spanish real estate and the existence of a higher-income, mobile population of consumers of urban spaces incentivised speculative investments based on flexible access to housing via digital platforms. Three significant policy decisions shaped this process in relation to the rental market in Madrid after the financial crisis. First, the new Ley de Arrendamientos Urbanos (Urban Rental Act) (2013) reduced the minimum duration of rental contracts from 5 to 3 years and consequently made the rotation of tenants easier; second, was the creation of real estate investment trusts, or Sociedades Anónimas Cotizadas de Inversión Inmobiliaria (SOCIMIs by its Spanish acronym) (Ley 16/2012); and third, the establishment of the 'golden visa' programme aimed to attract foreign investors to the Spanish real estate sector (which accounted for $6 \%$ of sales in 2018, according to Estadística Regional Inmobiliaria (2018: 80)). Thus, the 
arrival of international corporate landlords and digital platforms for holiday renting seems to have played an important role in a new surge of gentrification, helping to transform the housing market of Madrid. As an example, the investment fund Blackstone through its SOCIMI (Fidere) has acquired 1860 houses for $€ 128.5 \mathrm{M}$ from the Empresa Municipal de Vivienda y Suelo (Madrid's public housing authority) (Simón Ruiz, 2019; Vidal, 2018). Madrid has consequently climbed to the top of the league tables of international luxury housing investments (López Letón, 2019).

Although these processes of gentrification have been thoroughly studied from the perspective of the increase in housing prices and the settlement of new, higher class groups (Echaves García, 2017; Idealista.com, 2018; López García, 2018; Rodríguez López, 2017), the implementation of new regulations for the real estate market, in combination with the emergence of 'P2P tourism', 'homesharing', 'holiday' or 'short-term rentals' sharply changed this situation (Ardura, 2017; Gil, 2018), increasing the presence of tourists and lifestyle immigrants from higher-income countries and thus accelerating the rise of real estate prices and increasing economic speculation in Centro and beyond.

\section{Literature review}

The transnational character of real estate speculation and demand in Madrid leads to a new type of gentrification that has not yet been fully accounted for. This section examines these changes through the lens of the recent academic contributions regarding the mutation of gentrification processes. We examine the 'wave model' introduced by Hackworth and Smith (2001), later updated by Lees et al. (2008: 179) - as it permits the evaluation of the degree of maturation of gentrification processes through time by depicting their canonical stages. This model relates the different mutations of the gentrification processes to the global economic crisis. A more recent contribution to this wave model identifies a fifth wave of gentrification that can be considered as the transnational 'urban materialization of financialized or finance-led capitalism' (Aalbers 2019: 1) where, as Aalbers puts it, 'corporate landlords and platform capitalism' play a significant role. Earlier processes of gentrification in Madrid can be characterised as first and second wave. They affected central areas of the city, with later sporadic state-led processes, and involved local real estate actors. Meanwhile, the more recent processes are more akin to Aalbers' fifth wave. Despite the clarity of this qualitative frame and its obvious applicability to cities in the 'Global North', gentrification waves were essentially defined in an Anglo-American context. Therefore, they are not entirely transferable to other social, economic and political situations. The shift to the fourth wave explained in the model by the reconfiguration after the dot.com crisis, that is, the massive 'switch' of capital to real estate - barely affected a Spanish economy propelled by its own national real estate bubble, which burst simultaneously with the global financial crisis.

However, wave theories should also incorporate not just the temporal modifications of 'rent gaps' (Smith, 1979) and localised 'uneven development' (Smith, 1982) in relation to a changing political economy. They should also consider how markets for local real estate can be globalised by spacetime compression (Harvey, 1989). As Smith (2010: 19) has pointed out, cities now 'find themselves competing economically with each other across national borders in a way that would have been inconceivable in the 1970s'. Slater (2017) uses the term 'planetary rent gap', in which global financial agents, 
real estate promoters, public administrations and local populations interact in a very uneven way depending on the context to produce the optimal conditions for accumulation. From the vantage point of real estate capital, this competition extends to attracting globally mobile, higher-income real estate consumers to the spaces of the city cities whose amenities are also embellished by state institutions or public programmes for art and culture, yet another way in which the state 'leads' gentrification processes in Southern Europe. Furthermore, Spain's place as a main tourism destination also facilitates the exploitation of housing as a tourist asset (Janoschka et al., 2014). As Cocola-Gant (2018: 7-8) explains, in lowerincome economies, such as in South-western Europe, where tourism is an important economic sector, 'the consumption power of the middle-classes is smaller than in advanced economies, [and] tourism comes to supplant the lack of local demand that real estate capital needs for the realization of surplus value'.

In this context, the proliferation of shortterm rentals managed on digital platforms appears to be playing a significant role in transforming housing investment and markets (Barron et al., 2018; see also Sequera and Nofre, 2019). Although tourism gentrification has been described before in the case of cities such as New Orleans (Gotham, 2005) or Barcelona, in the case of Madrid it was not on the public agenda until the rise of digitally mediated holiday rentals, as residents began to see how the activity of these platforms 'threaten[ed] their right to stay put while making it increasingly difficult for residents to find affordable accommodation' (Cocola-Gant, 2016). Madrid's urban transformation helps us to better understand the particularities of gentrification in Southern Europe, where foreign real estate investment and mobile tourists are changing cities.

\section{Methodology}

Many high-income foreigners come to the city as tourists, for short stays. We focus here on this aspect of transnational gentrification - specifically, its relation to tourism. Access to short-term rentals provides tourists with cheaper alternatives to hotels, which are also more flexible ${ }^{4}$ and apparently more 'authentic' (e.g. 'live like a local') than traditional short-term residential rentals (Füller and Michel, 2014; Novy, 2019; Zervas et al., 2017). Our main hypothesis is that the proliferation of short-term rentals produces higher prices than the average traditional rent, potentially inducing transnational gentrification in some areas of Madrid - that is, an unaffordable rise in the cost of living compared with the local residents' disposable incomes, accompanied by a substitution of the resident population by wealthier international settlers. Despite the intuitiveness of this hypothesis, its verification is debated given the externalities that affect the housing market: overall housing demand, seasonality of tourism, density of touristic venues, supply distribution, accessibility by public transport, the approval of municipal ordinances regarding short-term rentals (ArduraUrquiaga et al., 2019). The most recent and comprehensive studies agree that the highest price increases in Barcelona have occurred in the most touristic areas of the city. However, the rise in prices cannot be exclusively attributed to Airbnb (García-López et al., 2019). To verify this hypothesis, we analysed some key indicators related to transnational gentrification: the growth of the number of residents from wealthy economic regions, the purchasing power of the local population and the dynamics of the real estate market based on empirical data from short-term accommodation platforms as well as traditional, long-term ones. Analysing these variables, we identify (1) areas where monthly rental prices have grown alongside the 
increase of short-term rentals on Airbnb; (2) areas where monthly rental prices have grown faster than the available income per capita; and (3) areas where the substitution of working-class immigrant populations occurred during and after the economic crisis of 2008.

First, we use local census data to identify international residents and areas that have experienced a decline in local population. Second, these data are contrasted with data from Inside Airbnb and Airdna to see which areas of the city have seen higher than average growth in short-term rental supply (Airdna.co, 2018; Cox, 2015). ${ }^{5}$ Next, we study the evolution of rental prices listed on traditional real estate platforms, using data from Idealista.com (one of Spain's most popular real estate websites), correlating it with the emergence of short-term rentals in some specific areas of the city (Hernández and Grasso, 2017; Idealista.com, 2018; López García, 2018; Sanz, 2018). At this point, some short-term rentals may be reflected in the statistics as empty houses therefore, they would not be substituting traditional rentals. This fact has been considered by comparing the number of empty houses with the increments of short-term rentals to avoid obtaining skewed results. Finally, the hypothesis can be confirmed by studying the population's income in the identified areas. This way we may conclude that the local emergence of short-term rentals in areas with small numbers of empty apartments, correlate with housing prices increasing above the disposable income of residents ${ }^{6}$ (Ayuntamiento de Madrid, 2015; ESNE, 2018; Vivus Finance, 2017) and verify the substitution of working-class immigrant residents with people from higherincome countries. All this provides a clearer picture of the key aspects of transnational gentrification which lead to potential displacement of residents. It must be stated, however, that the implicit complexity of gentrification processes and the level of aggregation of the analysed data can only show us the potential vulnerability of some areas of the city to population displacement. Further residential mobility data from the Madrid census would complement this research in the future.

\section{Results}

\section{Wealthier immigration}

As noted above, the Spanish recession accelerated population loss in the central district of Madrid. However, the district attracted international residents, who helped boost the total immigrant population by $5 \%$ from 2015 through January 2018. New immigrants settling in the area, however, have a new socio-economic profile. According to data from the yearly census, the number of people from wealthy geo-economic regions is still growing - in 2008, residents from EU15 or OECD countries barely reached $25 \%$ of the immigrant population in the city centre. Now these countries represent almost half of the foreigners living in the area. By contrast, the size of Latin American and especially African communities shrank dramatically.

This new composition of the immigrant resident community reflects a shift in the model of immigration (Figure 2). Whilst in the past, the central district was a preferred destination for people coming from underprivileged geo-economic regions searching for a conveniently located space within the urban system, today the area has become the popular choice for immigrants from wealthier countries. This shift is especially remarkable in the neighbourhoods where the most important tourist amenities are located - such as Palacio, Cortes and Sol or where there have recently been patterns of gentrification made evident by the settlement of local 'creative classes' (Sorando and Ardura, 2016, 2018). In some neighbourhoods, residents from wealthier OECD 


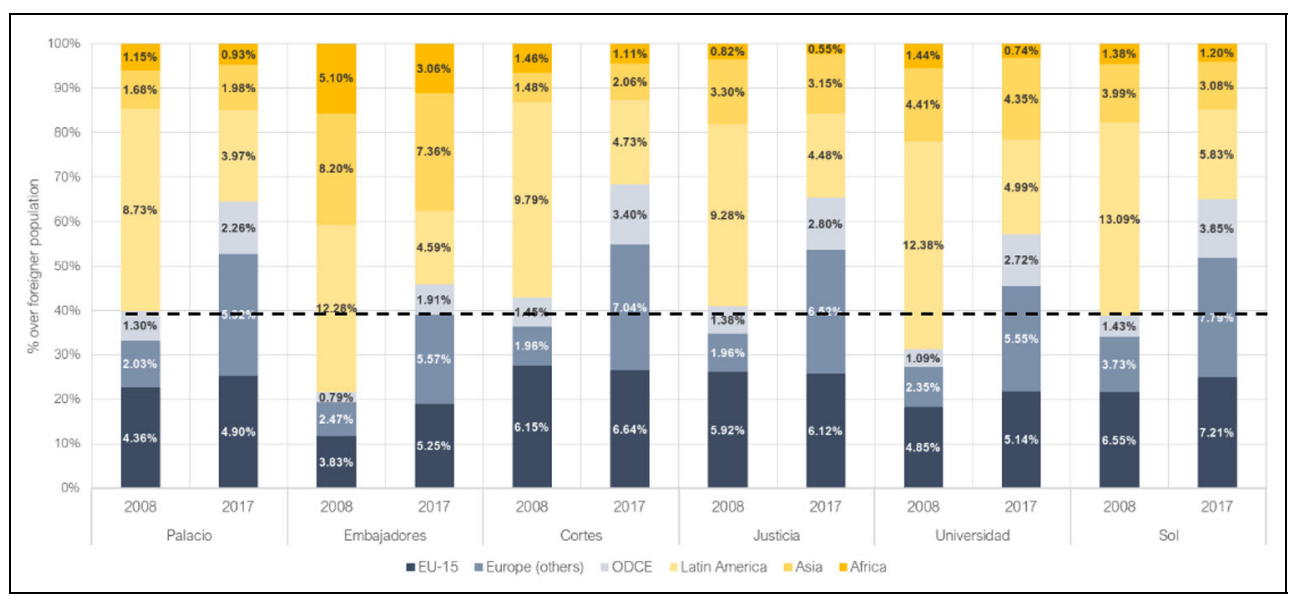

Figure 2. Composition of the immigrant population before and after the Spanish economic crisis by Madrid central district neighbourhoods.

Source: Authors. Data from Ayuntamiento de Madrid (2018a).

countries reach and exceed $60 \%$ of the immigrant population, having represented on average less than $40 \%$ before the crisis. Given that the data presented in this section have been gathered from the population census, the registered population has met the requirement of providing proof of residence in the area for more than three months. Therefore, it indicates a trend of residents coming from high-income countries and gaining access to housing, thus supporting the hypothesis that the city centre has become an emerging destination for lifestyle migrants, that is, relatively privileged social classes from higher-income countries, who may relocate for lifestyle and leisure reasons above labour market reasons (Benson and O'Reilly, 2009, 2014). However, many of these international residents from higherincome countries no doubt also work.

\section{Digital platforms and the touristic specialisation of the centre}

In conjunction with the settlement of new, higher-income migrants, Madrid has gained favour in recent years as a destination for short-stay visitors from the Global North. The data from the recently started 'Frontur' and 'Egatur' initiatives, carried out by the National Institute of Statistics, show that the city has recently experienced significant changes in the origin of incoming tourists, from being an established destination for national tourism to becoming an attractive option for short international visits. International arrivals by plane dropped between 2011 and 2013 but then grew by $38.5 \%$ - or $29.3 \%$ over 2008 arrivals (Ministerio de Transportes, Movilidad y Agenda Urbana, 2017; Rodríguez, 2016). Overnight hotel stays grew in a similar proportion after 2013 (Bacon and Garcia, 2018). However, the supply of hotel rooms has remained stable since 2013 (Ayuntamiento de Madrid, 2018b; Bacon and Garcia, 2018). This could be explained by the short duration of stays, in combination with a high stock of rooms and balanced demand throughout the year that translates into hotel occupancy rates below $70 \%$. However, the number of incoming international tourists has grown at a faster 
rate than the supply of hotel rooms and the occupancy rates of hotels and hostels. Whilst occupancy rates grew 5\% between 2015 and 2017 , international visitors increased by $15 \%$ - and national tourism decreased by $3 \%$. Over this period, the number of listings offered on Airbnb doubled (Figure 3). It stands to reason that short-term rental platforms are accommodating an important part of the increased number of visitors.

As the data reflect, the growth in international visitors corresponds with the skyrocketing growth of listings on Airbnb, which began in 2014. According to Airdna.co (July 2018) there were 29,588 listings in Madrid, 26,925 present on Airbnb - $91 \%$ of the total. According to Insideairbnb.com, the total number of listings in Madrid on Airbnb in July 2018 was $18,362 .^{7}$ Some hosts rent a spare room in their home periodically, while others use properties as full-time speculative investments and manage them through specialised holiday rent management companies $-41 \%$ of the listings are available all year round, 59\% are managed either by professionals or by owners of more than one apartment (Airdna.co, July 2018).

Over the 2015-2018 period, Embajadores (Lavapiés) and Universidad (Malasaña) were the locations where vacation rental platforms initially became more popular, coinciding with areas with the fastest growing rates of immigration from high-income countries and declining numbers of residents from lower-income countries. Meanwhile, the supply increased exponentially in the city centre, almost doubling the number of listings in the central neighbourhoods. In a location pattern that differs from that of hotels, vacation apartments have grown around a North-South axis across the district, where a large number of shopping franchises and souvenir stores are concentrated. ${ }^{8}$

Our findings show that the effect of short-term rentals on the traditional housing market may be considerable. Using the data available on Insideairbnb.com (July 2018), considering only listings available more than 90 days a year and differentiating how those listings are managed, we observed that only half of the filtered 11,224 listings in Madrid appeared to be offered under the terms of the sharing economy - hosting visitors in spare rooms during short periods of time or using an entire empty home for that purpose. There are 5264 offerings for 'complete apartments" ${ }^{\text {'9 }}$ managed by professional hosts - who manage more than two listings on the platform - which were most likely to have been removed from the traditional rental market. Centro accounts for more than $67 \%$ of them - 3530 apartments of the total 70,505 units in the district, including 27,885 rental units and 11,190 empty ones (INE, 2011).

The centre is where the Airbnb phenomenon has intensified (Figure 4) - presenting the highest density of short-term rentals in a short period of time. The concentration of tourist attractions in the district, the past gentrification of several areas, in combination with the new regulations for rentals, constituted an optimal setting for the adoption of the new rental technologies and the consequent transformation of the rental supply to host international newcomers. It is not surprising that Chueca, Malasaña and Lavapiés had the densest clusters of shortterm rentals since their implementation took place. From that moment, the residential fabric of the district became more and more appealing to landlords and real estate investors, causing the expansion of the compact cluster of holiday rentals running through the district's North-South axis.

\section{Short-term rentals beyond the Central district}

Meanwhile, the supply of vacation rentals grew in the vicinity of Centro: to the West, the neighbourhood of Puerta del Ángel; to 


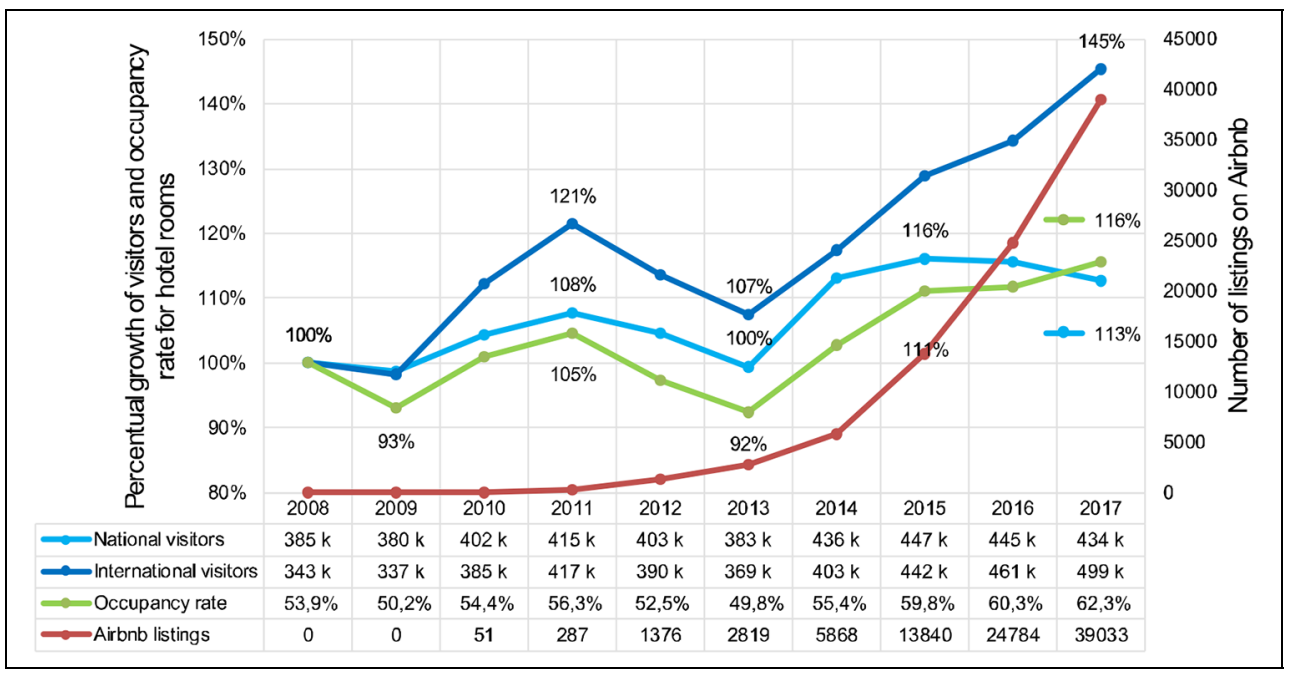

Figure 3. Number of visitors in Madrid compared with hotel occupancy rates and number of listings on Airbnb.

Source: Authors. Data from Ayuntamiento de Madrid (2018b) and Airdna.co (2018).

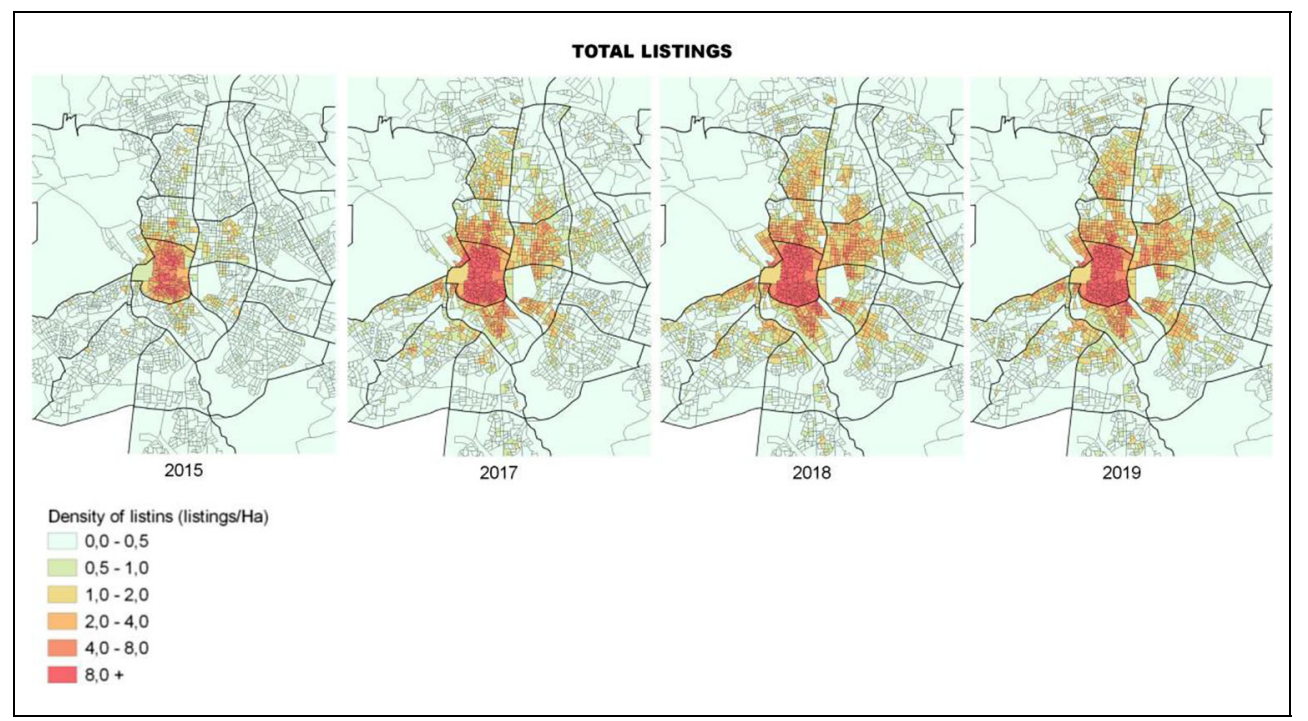

Figure 4. Airbnb Listing density by census sections, 2015-2019.

Source: Authors. Data from Insideairbnb.com.

the North, Chamberí and Tetuán; to the to the South, Arganzuela, Carabanchel and East, Barrio de Salamanca and Retiro (in the Usera. All these areas saw significant growth more affordable areas of these districts, tradi- in the number of listings between 2015 and tionally the wealthiest bastions of Madrid); 2018 (Airbnb, 2016). Given the lack of 
tourist attractions in these areas in comparison with the city centre, the presence of outliers of growth in some sectors of these districts is remarkable, indicating the emergence of new clusters of short-term rentals. However, the potential impact of the proliferation of short-term rentals in these districts is different, given their significant differences compared with Centro. Whilst all of them are well connected with the centre by public transport, residents' incomes and purchasing power vary considerably.

The southern, western and northern limits of the M-30 ring road provide access to significant housing supply that traditionally has responded to the needs of the working classes and lower-income immigrants. The housing prices in these areas plummeted during the economic crisis - thus maximising the possible benefits of new investment in devalued real estate. To give a concrete example, the areas closest to public transport - or to the central district in the case of Puerta del Ángel - have experienced the highest levels of growth, around three times the average number of listings of their districts. By contrast, the eastern and northern boundaries of the centre are home to the city's highest-income earners. There, the number of Airbnb listings has risen in proportion with that in lower-income neighbourhoods of the city centre - but the increase is concentrated in the lower-cost areas of these wealthy neighbourhoods, enabling them to garner much higher rents. Although the central district represents the vast majority of listed properties, its nearest neighbours are also providing opportunities for turning traditional rental units into short-term rental properties.

\section{Income and rent affordability}

As housing prices are expected to increase, the hypothesis of potential displacement of the local population is supported if the rise in rental prices is related to the increase in speculative investments in properties listed on short-term rental platforms, and if the proportion of the local residents' disposable income spent on housing increases as a result. To test this hypothesis, we considered the growth of holiday rentals, traditional rent prices and the population's income together. Given that homeowners are less likely to be displaced by the emergence of short-term rentals, only the rise of the cost of the rent over renters' incomes has been considered to evaluate the possibility of residential displacement. As noted above, the central district is receiving visitors from countries with higher income levels who have on average, therefore, greater purchasing power compared with both the local and immigrant communities living in the central district before the economic crisis started in 2008. It can be observed (Figure 6) that the overall foreign population (including migrants from the Global South) fell by $34 \%$ in the area between 2010 and 2014, the hardest times of the economic crisis. In the centre of Madrid the traditional housing rentals' price shrank 24\% from 2007 to 2014. The income in the area also decreased by $13 \%$ up until 2014.

This was the same year Airbnb began to take off in the city of Madrid, experiencing exponential growth until 2017. By that time, the Municipality had drafted an action plan to establish restrictive conditions for new short-term rentals within the most affected districts, which was to be approved in 2018 with the main goal of controlling the pressure of Airbnb on the housing market. However, the proposal was suspended. In parallel, the long-term rental price in the district grew by $33 \%$ after 2014 , situating the cost of rent at levels never seen before, even when compared with pre-crisis prices. During that period, the number of migrants living in Centro began to recover but at a much slower pace than housing prices, given the settlement of migrants from First World economies. 


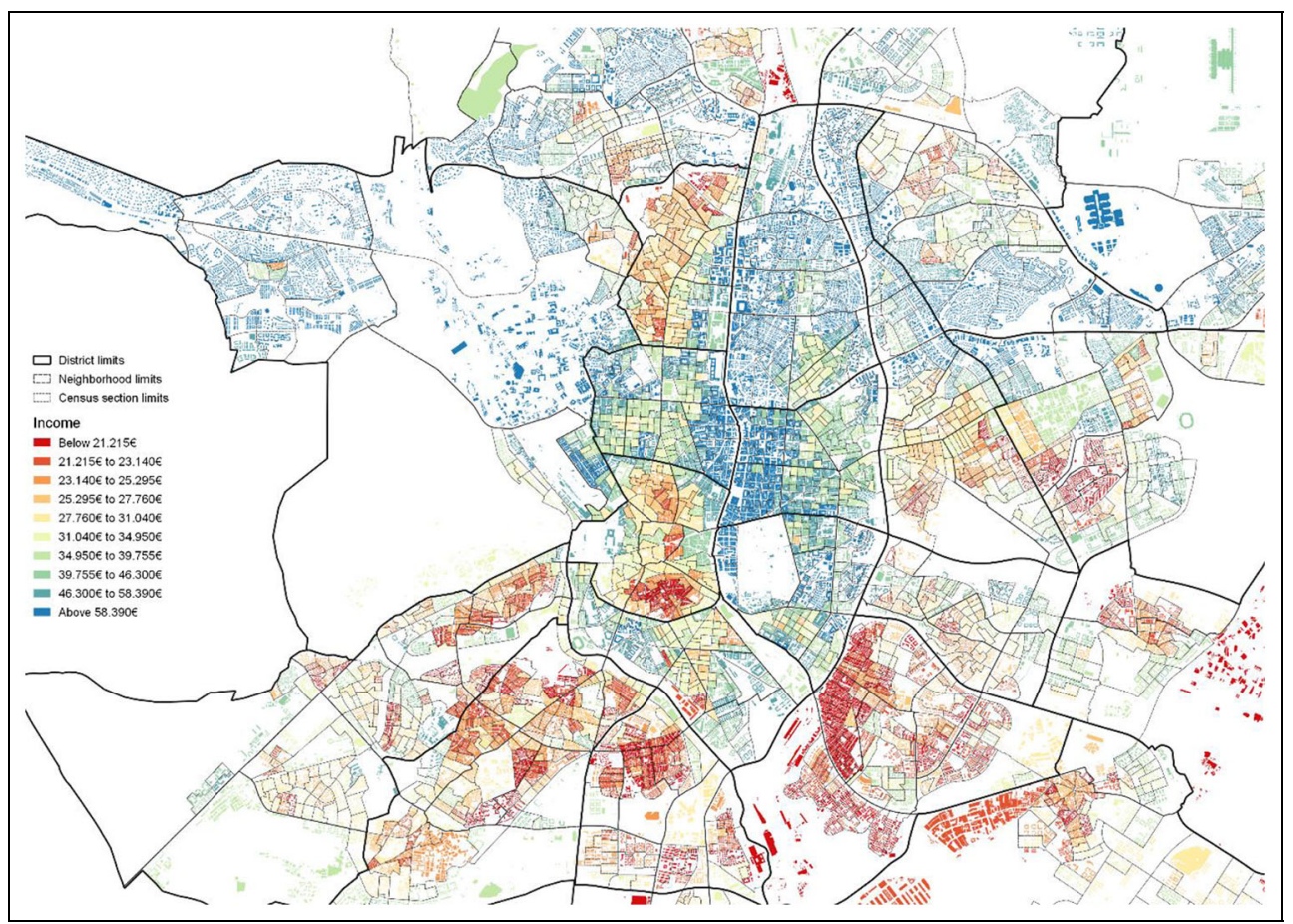

Figure 5. Madrid; income per capita in the 2014 census sections. Source: Authors. Data from Ayuntamiento de Madrid (20I5).

The correlation between the growth in rental prices and the emergence of shortterm rentals in Centro is clear. On average, a listing on the digital platform is expected to produce $100 \%$ more benefits and earnings than a traditional rental if it maintains an occupancy rate above $65 \%$ throughout the year (Ayuntamiento de Madrid, 2017). This may have subsequently led landlords to raise the price of rents according to these expected benefits, given that the market allows them to choose between either renting the property through the digital platform or traditionally renting it in an increased price bracket.

Beyond Centro, the growth of short-term rentals also coincides with the increase in the cost of rent in some areas, especially those best located and with better transport links with the centre. However, the increase in the number of listings is significantly lower. Despite that, the surge in rental prices is faster than what residents' purchasing power can keep up with. Given that the recession negatively affected income from 2009 until 2014 - and this income had not recovered by 2018, the end of the time frame considered in this study - and that rental prices grew by $39 \%$ between 2014 and 2018, and 9\% over prices in 2008, it is possible that lower-income groups were displaced from Centro and its inner suburbs when trying to renew rental contracts. Also, the fall in income could lead lower-income homeowners to list spare rooms to complement their wages, making some of the increase in short-term rentals an indicator of precariousness rather than tourism gentrification (Semi and Tonetta, 2019). Using income data (Figure 5), the evolution of longterm rental prices (Hernández and Grasso, 
2017) and the monthly price for complete apartments ${ }^{10}$ listed on Airbnb, we estimated the areas where the rising cost of rent could potentially lead to displacement because of unaffordable living expenses for the average resident.

First, we considered the case of an individual paying the full cost of rent, earning the average income for the area, and living in a $50 \mathrm{~m}^{2}$ single room apartment. Before 2014 , the cost of renting in the central district represented between $38.3 \%$ (Justicia) and $61 \%$ (Embajadores) of the average net income. Assuming the average growth of income and rental prices described above, the expansion of short-term rental platforms (Figure 6) coincided with rental price increases on long-term rentals that now take up $49.1 \%$ (Justicia) and $78.3 \%$ (Embajadores) of disposable income. Even as the traditional rental market bit in to residents' disposable income (from 10.8\% in Justicia to $17.3 \%$ in Embajadores), the average monthly rent of an equivalent apartment through short-term rental platforms represents between 62.1\% (Justicia) and 97\% (Sol) of the locals' net income (Table 2).

These significant increases in housing prices make the average resident especially vulnerable to displacement during this new wave of tourist gentrification. As prices increased, renters saw their purchasing power reduced, even though data suggest their economic situation improved after the recession - though it is important to note that observed economic improvements in the data might reflect the arrival of wealthier residents in an area rather than increased income for the existing population. The reduction of purchasing power might force them to either move to a different neighbourhood - confirming the hypothesis of gentrification - or to share the cost of the rent with others in order to afford it another form of displacement.
If we performed an equivalent analysis to assess the effects of digital short-term rental platforms on those rentals paid by more than one person, the data show how this alternative could mitigate the potential displacement of population. In those cases of shared rents, the loss of purchasing power ranged between 7.3\% (Justicia) and 11.6\% (Embajadores), deduced from rental prices which would represent between $32.8 \%$ (Justicia) and 52.2\% (Embajadores) of the average disposable income.

As seen in Table 2, the areas where shortterm rental services grew the most coincide with the lowest registered income. It is worth noting the case of Embajadores - the lowestincome area of the Centro district, where the share of low-income migration dramatically diminished during the recession. Airbnb has grown the most in this sector and the increase in cost of housing represents the highest losses of purchasing power in the city, validating the hypothesis of gentrification.

However, this phenomenon has not been exclusive to Embajadores-Lavapiés. Whilst people living in the wealthy north-east neighbourhoods (e.g. Almagro, Castellana, Salamanca) can afford rising rental prices, traditional working-class neighbourhoods such as Puerta del Ángel and Valdeacederas, both located next to the $\mathrm{M}-30$ ring-road and well connected to Centro, have experienced a similar pattern of falling non-housingrelated purchasing power resulting from increasing rental costs.

\section{Conclusion}

Although Madrid ranks amongst the world's 'alpha' cities ${ }^{11}$ it had experienced only medium range gentrification processes until 2013 - milder than those in Barcelona - that can be classified within the two first waves of gentrification processes (Hackworth and Smith, 2001), thus arguably in tension with 


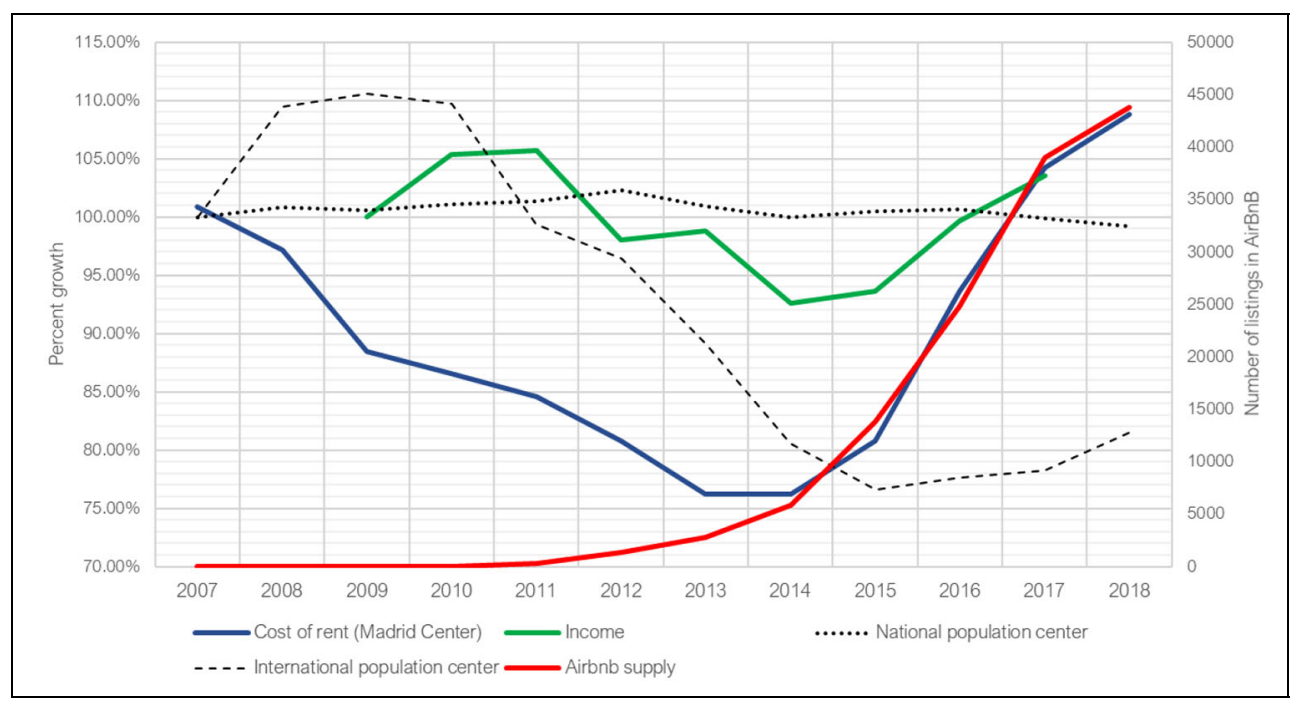

Figure 6. Evolution of international population, cost of the rent, income per capita and supply of shortterm rentals on Airbnb.

Source: Data from Ayuntamiento de Madrid (2018a) and Airdna.co (2018).

the idea of gentrification as a global strategy formulated by Smith (2002), since urban processes in Madrid at this point did not look at all like the gentrification experienced in paradigmatic Anglo-American examples. However, since 2013 we can argue that Madrid has been undergoing 'transnational gentrification' that 'connects redevelopment capital to housing demand not within a single city-region but transnationally, and thus creates new possibilities for profitable housing reinvestment - and new threats of displacement - in markets where such possibilities would not have existed on the basis of local demand alone' (Sigler and Wachsmuth, 2016: 2). This can be seen in the demographic statistics of new people arriving to live in Madrid. While visits from lower-income economies in the Global South have been in decline since the 2008 recession began, tourists and immigrants from higher-income economies such as the EU 15 and OECD especially the USA - have outstripped even national tourism in Madrid.
Given the fact that those countries are benefiting from being on the wealthy side of the global rent gap (Lees et al., 2015) in relation to the Spanish economy, their citizens can, on average, afford to pay higher prices for shorter stays, as long as the accommodation market is flexible and secure enough to access. This situation makes visitors from wealthy countries the main target of P2P accommodation services (Wachsmuth and Weisler, 2018). Therefore, it is not surprising that the most touristic areas of the city as well as either the closest or best-connected surrounding areas have witnessed the highest increases in short-term rentals through digital 'homesharing' platforms - amongst which Airbnb stands out.

This paper emphasises the hypothesis of gentrification as a cause of potential displacement of the local population given the unaffordable rise in housing expenses in some areas. The rapid increase in the holiday rental supply from 2013 onwards coincides in time with the arrival of wealthy 
Table 2. Available income and cost for individually paid $50 \mathrm{~m}^{2}$ rents in 2014 and 2017 in the Central district of Madrid.

\begin{tabular}{lllllr}
\hline Neighbourhood & $\begin{array}{l}\text { Monthly } \\
\text { income 20I4 }\end{array}$ & $\begin{array}{l}\text { Monthly } \\
\text { income } 2017\end{array}$ & $\begin{array}{l}50 \mathrm{~m}^{2} \text { rental } \\
\text { price 20I4 }\end{array}$ & $\begin{array}{l}50 \mathrm{~m}^{2} \text { rental } \\
\text { price 20I7 }\end{array}$ & $\begin{array}{l}50 \mathrm{~m}^{2} \text { rental } \\
\text { price Airbnb 20I7 }\end{array}$ \\
\hline Cortes & $1519.42 €$ & $1621.33 €$ & $664.05 €(43.7 \%)$ & $910.0 €(56.1 \%)$ & $1276.5 €(78.7 \%)$ \\
Embajadores & $1052.59 €$ & $1123.19 €$ & $642.16 €(61.0 \%)$ & $880.0 €(78.3 \%)$ & $967.5 €(86.1 \%)$ \\
Justicia & $1803.58 €$ & $1924.55 €$ & $690.81 €(38.3 \%)$ & $946.7 €(49.2 \%)$ & $1196.5 €(62.2 \%)$ \\
Palacio & $1567.22 €$ & $1672.34 €$ & $625.14 €(40.0 \%)$ & $856.7 €(51.2 \%)$ & $1244.8 €(74.4 \%)$ \\
Sol & $1296.77 €$ & $1383.74 €$ & $678.65(52.3 \%)$ & $930.0 €(67.2 \%)$ & $1342.9 €(97.0 \%)$ \\
Universidad & $1348.18 €$ & $1438.60 €$ & $654.32 €(48.5 \%)$ & $896.6 €(62.3 \%)$ & $1057.7 €(73.5 \%)$ \\
\hline
\end{tabular}

Sources: Ayuntamiento de Madrid (2018a), Idealista.com (2018) and Airdna.co (July 2018).

immigration, tourism and the escalation of prices for traditional rentals. Moreover, as Cocola-Gant (2016) suggested as a general pattern, the Madrid neighbourhoods that lost the most residents (Sol and Embajadores) between 2013 and 2017 also saw the greatest growth of holiday rentals, although the loss of population began earlier than the consolidation of the short-term rental market.

This emergence of digital platformmediated short-term rentals has intensified the previously initiated processes of gentrification in the district of Centro, and it has broadened the phenomenon to its most immediate surroundings although to a lesser degree, regardless of the income levels of the areas in question. Despite the disparity in income, the densification of the vacation rental supply in Puerta del Ángel (Western periphery), Tetuán (Northern periphery), Arganzuela (South end) and Barrio de Salamanca (East end, in its less expensive areas) has been similar. However, residents living in the first three of these neighbourhoods are more vulnerable to higher costs of living, given their significantly lower incomes. The data show how they may have either more limited access to housing or difficulty moving within the area after the consolidation of the vacation rental market.

To summarise, the gentrification processes in the case of Madrid Centro and the surrounding districts may be the result of the settlement of new residents arriving from countries on the positive side of the rent gap with Spain, in combination with an intensification of tourism that has made the holiday rental sector into 'the new battlefront' (Cocola-Gant, 2016), especially in Southern Europe. This new wave of transnational gentrification shows a strong presence of international real estate actors making use of platform-mediated short-term home rentals and turning them into one of their principal investments. This would make Madrid a prototypical case for Hackworth and Smith's theoretical frame, updated by Aalbers. The flexibilisation of the real estate market made possible by short-term rental platforms has intensified the commodification of housing in and beyond the city centre, rather than enhancing its use value through sharing.

\section{Acknowledgements}

We would like to thank Matthew Hayes, editor of this Special Issue, for his guidance and support through the publishing process. Added to the reviewers', his suggestions helped us to improve the overall structure and style of the article.

\section{Funding}

The author(s) received no financial support for the research, authorship, and/or publication of this article. 


\section{ORCID iDs}

Alvaro Ardura Urquiaga (D) https://orcid.org/ 0000-0002-7485-3642

Iñigo Lorente-Riverola (D) https://orcid.org/00000001-8161-8176

\section{Notes}

1. A movement of counter-cultural renaissance in Madrid during the post-Franco era, based in the underground pop music scene.

2. Currently large communities from Senegal and Bangladesh coexistent with a strong Chinese commercial activity and a significant Moroccan population.

3. The average for the EU was only around $7.5 \%$ according to Eurostat (available at: http://ec.europa.eu/eurostat/product?code $=$ prc_hpi\&mode $=$ view).

4. The 'Law for Urban Rentals' (Ley de Arrendamientos Urbanos) of Madrid covers yearly renting contracts, forcing their extension up to 3 years from the date of signing at the renter's demand.

5. These web pages study the supply of rooms and apartments in the city of Madrid by scraping and cleaning the data shown on Airbnb, making this information and other relevant insights available for download.

6. The disposable income has been calculated by subtracting the income per capita from the estimated cost of living in Madrid.

7. The data source, airdna.co, uses different filtering protocols than Insideairbnb.com. Also, airdna.co added the listings served on homeaway.com since June 2017. Consequently, different counts among platforms can be expected.

8. A graphic representation of this can be found at http://datos.elespanol.com/proyectos/airbnb/.

9. This is a conservative approach, which acknowledges that a significant number of users may, in fact, be sharing their apartments' spare capacity. However, as some municipalities are passing ordinances to control the professionalisation of the short-term rentals, the type of listings may change (Shatford, 2017).

10. On average, an apartment rented by month through Airbnb has a 30\% discount over its nightly price - increasing its competitivity with the traditional rental market.

11. According to the Global City Network classification, available at: http://www.lboro.ac. uk/gawc/gawcworlds.html.

\section{References}

Aalbers M (2019) Revisiting 'The changing state of gentrification' - Introduction to the Forum: From third to fifth-wave gentrification. Tijdschrift voor Economische en Sociale Geografie 110(1): 1-11.

Airbnb (2016) 17 Neighborhoods to watch in 2017: Airbnb data reveals trending neighborhoods for travel. Available at: https://press.atairbnb. com/17-neighborhoods-to-watch-in-2017airbnb-data-reveals-trending-neighborhoodsfor-travel/ (accessed 1 July 2018).

Airdna.co (2018) Madrid, Spain. Available at: https://www.airdna.co/market-data/app/es/ madrid/madrid/overview (accessed 1 July 2018).

Ardura A (2017) La incidencia de la proliferación del alojamiento turístico en viviendas en el centro de Madrid. In: 3er encuentro europeo Vivre la ville. Available at: http://www.vivrela-ville.fr/wp-content/uploads/2017/03/Vivre La-Ville-Madrid-2017_PonenciaTurismoES.pdf (accessed 1 July 2018).

Ardura-Urquiaga Á, Lorente-Riverola Í, MohínoSanz I, et al. (2019) 'No estamos tan mal como Barcelona': Análisis de la proliferación y regulación de las viviendas de uso turístico en Madrid y Barcelona. Boletín de La Asociación de Geógrafos Españoles 83: 1-47.

Arias Sans A and Quaglieri A (2016) Unravelling airbnb: Urban perspectives from Barcelona. Reinventing the Local in Tourism: Producing, Consuming and Negotiating Place 73: 209.

Ayuntamiento de Madrid (2015) Renta neta media de los hogares (Urban Audit). Available at: https://www.madrid.es/portales/muni madrid/es/Inicio/El-Ayuntamiento/Estadis tica/Areas-de-informacion-estadistica/Econo mia/Renta/Renta-neta-media-de-los-hogaresUrban-Audit-/?vgnextfmt $=$ default\&vgnextoi $\mathrm{d}=65 \mathrm{e} 0 \mathrm{c} 19 \mathrm{a} 1666 \mathrm{a} 510 \mathrm{VgnVCM} 1000001 \mathrm{~d} 4 \mathrm{a} 90$ 0aRCRD\&vgnextchannel $=$ ef863636b44b4210 Vgn VCM2000000c205a0aRCRD (accessed April 2018). 
Ayuntamiento de Madrid (2017) La Oferta de Alojamiento Turístico en Madrid: Características y Distribución Territorial. Report by Red2Red consultants for Área de Desarrollo Urbano Sostenible.

Ayuntamiento de Madrid (2018a) Ayuntamiento de Madrid. Banco de datos. Available at: http://www-2.munimadrid.es/CSE6/jsps/ menuBancoDatos.jsp (accessed April 2018).

Ayuntamiento de Madrid (2018b) Encuesta de Ocupación hotelera. Available at: http://www2.munimadrid.es/CSE6/jsps/menuBancoDa tos.jsp (accessed April 2018).

Bacon P and Garcia C (2018) Market report: Madrid, Spain. Horwath HTL: Hotel, Tourism and Leisure, 5 February. Available at: http:// horwathhtl.com/wp-content/uploads/sites/2// 2018/02/HHTL_MR-SPAIN_Feb.pdf (accessed 1 July 2018).

Barron K, Kung E and Proserpio D (2018) The sharing economy and housing affordability: Evidence from Airbnb. SSRN Electronic Journal. DOI: 10.2139/ssrn.3006832 (accessed 1 July 2018).

Benson M and O'Reilly K (2014) New horizons in lifestyle migration research: Theorising movement, settlement and the search for a better way of life. In: Benson $\mathrm{M}$ and Osbaldiston $\mathrm{N}$ (eds) Understanding Lifestyle Migration: Theoretical Approaches to Migration and the Quest for a Better Way Of Life. Basingstoke: Palgrave Macmillan, pp. 1-26.

Cocola-Gant A (2016) Holiday rentals: The new gentrification battlefront. Sociological Research Online 21(3). Available at: https: //journals.sagepub.com/doi/10.5153/sro.4071 (accessed 1 July 2018).

Cocola-Gant A (2018) Tourism gentrification. In: Lees L and Phillips M (eds) Handbook of Gentrification Studies. Cheltenham and Northampton: Edward Elgar, pp. 281-293.

Cocola-Gant A and López-Gay A (2020) Transnational gentrification, tourism and the formation of 'foreign only' enclaves in Barcelona. Urban Studies (in press). DOI: 10.1177/ 0042098020916111.

Cox M (2015) Adding data to the debate. Inside Airbnb. Avaliable at: http://insideairbnb.com/ (accessed 1 July 2018).
Davidson M (2008) Spoiled mixture - Where does state-led 'positive' gentrification end? Urban Studies 45(12): 2385-2405.

Echaves García A (2017) El difícil acceso de los jóvenes al mercado de vivienda en España: Precios, regímenes de tenencia y esfuerzos. Cuadernos de relaciones laborales 35(1): 127-149.

ESNE (2018) Coste de vida en Madrid. Available at: http://www.esne.es/servicios/welcome-eras mus/coste-de-vida-en-madrid/ (accessed 1 July 2018).

Esradística Registral Inmobiliaria (ERI) (2018) Anuario 2018. Registradores de España.

Florida R (2002) The Rise of the Creative Class. And How It's Transforming Work, Leisure and Everyday Life. New York: Basic Books.

Füller H and Michel B (2014) 'Stop being a tourist!' New dynamics of urban tourism in BerlinKreuzberg. International Journal of Urban and Regional Research 38(4): 1304-1318.

Garcia-López M-À, Jofre-Monseny J, Martínez Mazza R, et al. (2019) Do short-term rental platforms affect housing markets? Evidence from Airbnb in Barcelona. SSRN Electronic Journal. Available at: https://papers.ssrn.com/ sol3/papers.cfm?abstract_id $=3428237$ (accessed 1 July 2018).

García Pérez E (2014) Gentrificación en Madrid: De la burbuja a la crisis. Revista de Geografía Norte Grande 58(5-6): 71-91.

Garnier JP (2017) El espacio urbano, el Estado y la pequeña burguesía intelectual: La radicalidad crítica en cuestión. In: Tello R (ed.) JeanPierre Garnier: Un sociólogo urbano a contracorriente. Barcelona: Ed. Icaria, pp. 189-202.

Gil J (2018) El conflicto de Airbnb aterriza sobre Madrid. Diario Público, 11 January. Available at: http://blogs.publico.es/contraparte/2018/ 01/11/el-conflicto-de-airbnb-aterriza-sobremadrid-2a-parte/ (accessed 1 July 2018).

Götte D (2014) De la transición española a la movida madrileña. Munich: GRIN Verlag.

Hackworth J and Smith N (2001) The changing state of gentrification. Tijdschrift voor economische en sociale geografie 92(4): 464-477.

Hammel DJ (1999) Gentrification and land rent: A historical view of the rent gap in Minneapolis. Urban Geography 20(2): 116-145. 
Harvey D (1989) The Condition of Postmodernity: An Enquiry into the Origins of Cultural Change. Cambridge, MA: Blackwell.

Hernández A and Grasso D (2017) ¿Buscas alquiler en Madrid o Barcelona? Este mapa muestra dónde te lo puedes permitir. El Confidencial. 1 September. Available at: https://www.elconfi dencial.com/vivienda/2017-09-01/alquiler-pre cio-barrios-madrid-barcelona_1435196/ (accessed 1 July 2018).

Idealista.com (2018) Housing prices report 2018. Available at: https://www.idealista.com/ informes-precio-vivienda (accessed 1 July 2018).

Instituto Nacional de Estadística (INE) (2011) Censo de Población y Vivienda. Available at: https://www.ine.es/censos2011_datos/cen11_ datos_inicio.htm (accessed 1 July 2018).

Janoschka M, Sequera J and Salinas L (2014) Gentrification in Spain and Latin America A critical dialogue. International Journal of Urban and Regional Research 38(4): 1234-1265.

Justo A (2011) Transformaciones en el barrio de Malasaña. Hacia la gentrificación. Viento Sur 116: 73-79.

Leal J (2004) Segregation and social change in Madrid metropolitan region. The Greek Review of Social Research 113: 81-104.

Lechado JM and García JML (2005) La movida: Una crónica de los 80. Madrid: EDAF.

Lees L, Shin HB and López-Morales E (2015) Global Gentrifications: Uneven Development and Displacement. Bristol: Policy Press.

Lees L, Slater T and Wyly E (2008) Gentrification. London: Routledge.

Ley D (1996) The New Middle Class and the Remaking of the Central City. Oxford: Oxford University Press.

Ley 16/2012, de 27 de diciembre, por la que se adoptan diversas medidas tributarias dirigidas a la consolidación de las finanzas públicas y al impulso de la actividad económica. BOE. Boletín Oficial del Estado, pp. 88, 097-88, 155.

López de Lucio R, et al. (2016) Madrid 19002010. Guía de Planeamiento y diseño urbano (Madrid 1900-2010. Urbanism and Urban Design Guide). Madrid: Ayuntamiento de Madrid.
López García A (2018) Radiografía del Mercado de la vivienda 2017-2018. Fotocasa. Available at: http://prensa.fotocasa.es/wp-content/ uploads/2018/05/Radiograf\%C3\%ADa-delmercado-de-la-vivienda-2017-2018-BAJA.pdf (accessed 1 July 2018).

López Letón S (2019) Madrid es la tercera ciudad del mundo donde más casas de lujo se buscarán este año. El País, 22 March. Available at: https://elpais.com/economia/2019/03/20/ vivienda/1553099878_898631.html (accessed 1 July 2018).

Ministerio de Transportes, Movilidad y Agenda Urbana (2017) Tráfico comercial por aeropuertos. Aeropuerto de Adolfo SuarezMadrid-Barajas. Available at: http://www.fo mento.gob.es $/ \mathrm{BE} /$ ?nivel $=2$ \&orden $=03000000$ (accessed 1 July 2018).

Novy J (2019) Urban tourism as a bone of contention: Four explanatory hypotheses and a caveat. International Journal of Tourism Cities 5(1): 63-74.

Pérez N, González M, Sevillano L, et al. (2015) Dormir en el limbo: Radiografia de Airbnb. El Español, 21 November. Available at: http:// datos.elespanol.com/proyectos/airbnb/ (accessed 1 July 2018).

Red2Red Consultores (2017) Análisis del Impacto de las Viviendas de Uso Turístico en el Distrito Centro. Madrid. Available at: https://www.madrid.es/UnidadesDescentralizadas/UDCMedios /noticias/2017/05Mayo/05viernes/Notasprensa/ ficheros/Informe_final_5_mayo vivendas uso turístico (1).pdf (accessed 1 July 2018).

Rodríguez P (2016) Sorprendente evolución del turismo en Madrid $\mid$ Mind the blog Universidad Europea. Available at: https://blog.universida deuropea.es/es/turismo/viajes-y-turismo/sorprendente-evolucion-del-turismo-en-madrid (accessed 1 July 2018).

Rodríguez López J (2017) Las viviendas que pudieron hundir la economía española. La caída del mercado de vivienda y sus consecuencias. Cuadernos de relaciones laborales 35(1): 71-99.

Sanz E (2018) Alquileres: ¿Alquiler turístico vs tradicional? Solo es más rentable a partir del $60 \%$ de ocupación. 27 June. Available at: https:// www.elconfidencial.com/vivienda/2018-06-27/ alquiler-turistico-rentabilidad-alquiler-tradi cional-precios_1584220/(accessed 1 July 2018). 
Semi G and Tonetta M (2019) Plateformes locatives en ligne et rente urbaine à Turin: Les classes moyennes face à l'austérité. Annales de Géographie 727(3): 40.

Sequera J (2013) Las politicas de gentrificación en la ciudad neoliberal. Nuevas clases medias, producción cultural y gestión del espacio público. El caso de Lavapiés en el centro histórico de Madrid. PhD Thesis, Universidad Autónoma de Madrid, Spain.

Sequera J and Janoschka M (2015) Gentrification dispositifs in the historic centre of Madrid: A re-consideration of urban governmentality and state-led urban reconfiguration. In: Lees L, Shin HB and López-Morales E (eds) Global Gentrifications: Uneven Development and Displacement. Bristol: Policy Press, pp. 375-394.

Sequera J and Nofre J (2019) Touristification, transnational gentrification and urban change in Lisbon: The neighbourhood of Alfama. Urban Studies. Epub ahead of print 17 December 2019. DOI: 10.1177/00420980 19883734.

Shatford S (2017) Is Airbnb regulation impacting short-term rental growth? AIRDNA. Available at: https://www.airdna.co/blog/effects-airbnbregulation (accessed 1 July 2018).

Sigler T and Wachsmuth D (2016) Transnational gentrification: Globalisation and neighbourhood change in Panama's Casco Antiguo. Urban Studies 53(4): 705-722.

Simón Ruiz A (2019) Blackstone abre la puerta a la venta de pisos sociales comprados en Madrid. Available at: https://cincodias.elpais. com/cincodias/2019/04/23/companias/1556045 344_333951.html (accessed 1 July 2018).

Slater T (2017) Planetary rent gaps. Antipode 49: 114-137.
Smith N (1979) Toward a theory of gentrification: A back to the city movement by capital, not people. Journal of the American Planning Association 45(4): 538-548.

Smith N (1982) Gentrification and uneven development. Economic Geography 58(2): 139.

Smith N (2002) New globalism, new urbanism: Gentrification as global urban strategy. Antipode 34(3): 427-450.

Smith N (2010) Uneven Development: Nature, Capital, and the Production of Space. University of Georgia Press.

Sorando D and Ardura A (2016) First we Take Manhattan. La destrucción creativa de las ciudades. Madrid: Catarata.

Sorando D and Ardura A (2018) Procesos y dinámicas de gentrificación en las ciudades españolas. Papers. Regió Metropolitana de Barcelona 60: $34-47$.

Vidal L (2018) 'Los "fondos buitre" en la ciudad, una cuestión de soberanía?' Opinión. Barcelona: CiDOB. Available at: https://www.cido b.org/en/publications/publication_series/opin ion/ciudades_globales/els_fons_vol tor_a_la_ ciutat_una_queestio_de_sobirania/(language)/ cat-ES (accessed 1 July 2018 ).

Vivus Finance (2017) ¿Cuánto cuesta vivir en Madrid? Principales gastos. Available at: https://www.vivus.es/blog/economia-de-hoy/ cuanto-cuesta-vivir-en-madrid/ (accessed 1 July 2018).

Wachsmuth D and Weisler A (2018) Airbnb and the rent gap: Gentrification through the sharing economy. Environment and Planning A: Economy and Space 50(6): 1147-1170.

Zervas G, Proserpio D and Byers JW (2017) The rise of the sharing economy: Estimating the impact of Airbnb on the hotel industry. Journal of Marketing Research 54(5): 687-705. 